\title{
ANALISIS PENGARUH BAURAN PEMASARAN JASA TERHADAP PERSEPSI KUALITAS STBA JIA BEKASI
}

\author{
Ali Khamainy \\ Sekolah Tinggi Bahasa Asing JIA, Bekasi, Indonesia \\ ali.k@stba-jia.ac.id
}

\begin{abstract}
Abstrak
Penelitian ini menganalisis pengaruh bauran pemasaran jasa (7P) terhadap persepsi kualitas sebagai langkah strategik dalam pengambilan keputusan dalam upaya proses pengembangan. Responden dari penelitian ini berjumlah 100 responden, dimana responden adalah para penguna jasa pada Sekolah Tinggi Bahasa Asing JIA yaitu Mahasiswa yang berstatus aktif. Alat analisa data yang digunakan adalah Structural Equation Modeling (SEM) pada program LISREL 8.70. Hasil analisis data penelitian ini menunjukkan model dan hasil penelitian dapat diterima dengan baik. Dan selanjutnya hasil penelitian ini membuktikan Produk "Product" memiliki pengaruh positif serta tingkat hubungan yang sangat kuat terhadap persepsi kualitas dibuktikan dengan nilai koefisien konstruk 0,87. Bentuk Fisik "Physical Evident" memiliki pengaruh positif serta tingkat hubungan yang kuat terhadap persepsi kualitas dibuktikan dengan nilai koefisien konstruk 0,78. Orang "People" memiliki pengaruh positif serta tingkat hubungan yang cukup kuat terhadap persepsi kualitas dibuktikan dengan nilai koefisien konstruk 0,65. Promosi "Promotion" memiliki pengaruh positif serta tingkat hubungan yang cukup kuat terhadap persepsi kualitas dibuktikan dengan nilai koefisien konstruk 0,58. Harga "Price" memiliki pengaruh positif serta tingkat hubungan yang cukup kuat terhadap persepsi kualitas dibuktikan dengan nilai koefisien konstruk 0,47. Tempat "Place" memiliki pengaruh positif serta tingkat hubungan yang cukup kuat terhadap persepsi kualitas dibuktikan dengan nilai koefisien konstruk 0,46 dan Proses "Process" memiliki pengaruh positif serta tingkat hubungan yang lemah terhadap persepsi kualitas dibuktikan dengan nilai koefisien konstruk 0,36. Implikasi manajerial dan agenda penelitian juga dibahas pada penelitian ini.
\end{abstract}

Kata Kunci: Bauran Pemasaran Jasa, Persepsi Kulitas

\begin{abstract}
This research analyzes the effect of the services marketing mix (7P) on the perceived quality as a strategic step in the decision making process of the development effort. Respondents of this research were 100 respondents, of which respondent is the user services at the School Foreign Language Students JIA is an active status. Data analysis tool used is the Structural Equation Modeling (SEM) in LISREL 8.70 software. The results of this study indicate data analysis models and results were well received. And subsequent research proves "Product" has a positive and a very strong level of perception of quality is evidenced by the coefficient construct 0.87. "Physical Evident" has a positive and strong relationship to the level of perceived quality construct as evidenced by the coefficient construct 0.78. "Physical Evident" has a positive and strong relationship to the level of perceived quality construct as evidenced by the coefficient construct 0.78. "People" have a positive influence and a strong enough relationship level to the perception of quality is evidenced by the coefficient construct 0.65. "Promotion" has a positive and strong enough relationship level to the perception of quality is evidenced by the coefficient construct 0.58. "Price" has a positive and strong enough relationship level to the perception of quality is evidenced by the coefficient construct 0.47. "Place" has a positive and strong enough relationship level to the perception of quality is evidenced by the coefficient construct 0.46 and the last is "Process" has a positive and a weak relationship to the level of perceived quality construct as evidenced by the coefficient 0.36. Managerial implications and research agenda are also discussed in this study.
\end{abstract}

Keywords: Services Marketing Mix, Perceived Quality 


\section{PENDAHULUAN}

Pada era millenium ketiga ini merupakan saat terjadinya berbagai perubahan yang besar dalam kehidupan masyarakat dunia. Salah satu tolok ukur kemajuan suatu masyarakat di suatu negara dari pertumbuhan sektor jasanya. Di negara maju sektor jasa menjadi semakin dominan dengan semakin tingginya tingkat perekonomian.

Untuk saat ini banyak sekali organisasi yang menggunakan seni perencanaan strategi bauran pemasaran yaitu proses manajerial untuk mengembangkan dan mempertahankan supaya tujuan, keahlian dan sumber daya organisasi tetap sesuai dengan peluang di pasar yang senantiasa berubah ubah. Perencanaan strategis bertujuan untuk membentuk bisnis, produk, layanan dan pesan organiasasi agar mencapai pertumbuhan yang telah ditargetkan. Karena bauran pemasaran dan keunggulan bersaing merupakan salah satu hal yang sangat penting bagi kelangsungan suatu organisasi.

Oleh sebab itu dalam penelitian ini ingin mencoba melakukan penelitian untuk mengetahui seberapa besar pengaruh bauran pemasaran jasa terhadap persepsi kualitas pendidikan yang sudah digunakan. Adapun objek penelitian ini adalah konsumen pengguna jasa pendidikan dalam hal ini mahasiswa STBA JIA. Tujuan mengetahui persepsi tersebut guna menentukan keputusan dalam memprioritaskan pengembangan kualitas berdasarkan bauran pemasaran jasa.

Berdasarkan uraian pada latar belakang, dapat didentifikasi beberapa masalah penelitian sebagai berikut:

1. Bagaimana pengaruh secara signifikan ketujuh kinerja pelayanan STBA JIA yang mengandung unsur 7P yaitu (Product, Price, Place, Promotion, People, Process, dan Physical Evidence) terhadap persepsi kualitas STBA JIA Bekasi?

2. Bagaimana urutan pengaruh ketujuh kinerja pelayanan STBA JIA yang mengandung unsur 7P yaitu (Product,
Price, Place, Promotion, People, Process, dan Physical Evidence) terhadap persepsi kualitas STBA JIA Bekasi?

\section{Definisi Pemasaran dan Jasa Definisi Pemasaran}

Pemasaran merupakan hal pokok yang dilakukan oleh organisasi untuk memepertahankan hidupnya, untuk mengembangkan usahanya dan untuk mendapatkan laba bagi perusahaannya atau untuk dapat keberlanjutan dalam proses pengembangan.

Menurut Kotler Philip, 1987 hal. 2 [1] mendefinisikan pemasaran adalah kegiatan manusia yang diarahkan untuk memenuhi kebutuhan dan keinginan melalui proses pertukaran. Tujuan pemasaran menurut Peter Ducker dalam Kotler Philip, 1987 hal.2 [1] adalah membuat agar penjualan berlebihan - lebihan dan mengetahui serta memahami konsumen dengan baik sehingga produk atau pelayanan cocok dengan konsumen tersebut dan laku dengan sendirinya.

\section{Definisi Jasa}

Definisi jasa Menurut Kotler Philip, 1988 hal. 465 [2] Jasa adalah segala kegiatan atau manfaat yang bisa ditawarkan oleh satu pihak kepada pihak lain yang pada dasarnya tidak bisa diraba dan tidak menghasilkan kepemilikan apapun.

Menurut Czinkota dan Ronkainen dalam Bernard. T Widjaja, 2009 hal. 7 [3] Karakteristik jasa dalam pemasaran jasa (services) terdapat faktor karakteristik unik jasa yang berbeda dari pemasaran produk (goods). Keunikan karakteristik jasa dibandingkan produk terletak pada 4 sifat diantaranya :

a) Intangibility merupakan sifat jasa yang tidak berwujud dan diterima konsumen sebagai performance yang hanya dapat dirasakan.

b) Inseparability mencerminkan tidak terpisahnya antara provider dan konsumennya, keterlibatan konsumen dalam proses delivery jasa dalam production process. 
c) Variability menunjukan bahwa performance jasa sangat sulit untuk dikontrol dan sangat bersifat relatif baik dari output provider maupun persepsi penerimaan konsumen.

d) Perishability merupakan salah satu keterbatasan jasa, mengingat proses dan penggunaan dilakukan dalam waktu bersamaan dan tidak memungkinkan dilakukan penyimpanan

\section{Bauran Pemasaran}

Menurut Kotler Philip, 1987 hal.41 [1]

Bauran Pemasaran ialah serangkaian variabel pemasaran terkendali yang dipakai oleh perusahaan untuk menghasilkan tanggapan yang dikehendaki perusahaan dari pasar sasarannya. Bauran pemasaran terdiri dari segala hal yang bisa dilakukan untuk mempengaruhi permintaan atas produknya. Beberapa kemungkinan itu bisa dikumpulkan ke dalam 4 kelompok variabel yang dikenal " $4 \mathrm{P}^{\text {" }}$ yaitu Product (Produk), Price (Harga), Place (Tempat), dan Promotion (Promosi), selanjutnya menurut Glyn dan Barnes dalam Bernard. T Widjaja, 2009 hal. 9 [3] untuk bauran pemasaran jasa (Services Markrting Mix) dilengkapi dengan "3P" yaitu People (Orang), Process (Proses) dan Physical Evidence (Bukti Fisik) sehingga biasa disebut "7P". Selanjutnya menurut Lupiyoadi Rambat, 2001 hal. 17 [4], bahwa “ sebagai suatu bauran pemasaran jasa, elemen tersebut (produk, harga, promosi, tempat, orang proses, pelayanan) saling mempengaruhi satu sama lain sehingga bila salah satu tidak tepat perorganisasiannya akan mempengaruhi strategi pemasaran secara keseluruhan.

\section{Kerangka Berpikir}

Berdasarkan uraian diatas maka dalam hal memberikan alur fikir terhadap penelitian ini, maka dibentuk keterkaitan antara variabel yang menjadi topik pembahasan menarik karena memiliki 42 variabel laten yang merupakan konsep abstrak sebagai contoh : Prilaku orang, sikap, perasaan dan motivasi. Sehingga variabel laten ini hanya dapat diamati secara tidak langsung dan tidak sempurna melalui efeknya pada variabel teramati, untuk itulah penelitian ini akan menggunakan pendekatan Structural Equation Modelling (SEM) seperti yang akan disajikan pada gambar kerangka berpikir dengan bentuk Structural Equation Modelling (SEM) yang selanjutnya akan dioleh menggunakan Program Software LISREL 8.70 .

\section{METODOLOGI PENELITIAN Metode Penelitian}

Metode penelitian yang akan digunakan adalah metode survey dengan mengumpulkan data melalui instrumen penelitian dan menyebarkan kuesioner kepada 50 orang mahasiswa yang hasilnya kemudian diolah menggunakan bantuan software SPSS untuk membantu dalam hal melihat apakah valid dan realibel kemudian selanjutnya setelah semua pertanyaan di kuesioner dinyatakan valid dan realibel, peneliti menyebar kuesioner tahap kedua kepada 100 orang responden mahasiswa sebagai data penelitian.

Penelitian ini menggunakan metode deskriptif dengan pendekatan kuantitatif. Metode statistik deskriptif digunakan untuk menjelaskan permasalahan yang terjadi perihal data dari penelitian. Sedangkan metode kuantitatif digunakan untuk menjelaskan pengaruh variabel bebas terhadap variabel terikat pada penelitian ini.

\section{Teknik Pengumpulan Data}

Teknik pengumpulan data dilakukan dengan cara penelitian lapangan (field research) adalah proses pengumpulan data yang bersifat aktual melalui pengamatan langsung dengan cara penyebaran kuisioner untuk mendapatkan data primer, sedangkan untuk mendapatkan data sekunder berasal dari studi pustaka dan literatur yang terkait yang biasa disebut penelitian kepustakaan (library research).

\section{ANALISIS DAN PEMBAHASAN Analisis Structural Equation Modeling (SEM) dengan LISREL 8.70}


Setelah diketahui seluruh instrument valid dan reliable maka dilanjutkan menggunakan analisis menggunakan metode Structural Equation Modeling (SEM) menggunakan program software LISREL 8.70. dari segi metodologi, SEM memainkan berbagai peran diantaranya sebagai sisitem persamaan simultan, analisis kausal linier, analisis lintasan (path analysis), analysis of covariance structure, dan model persamaan structural. Meskipun demikian ada beberapa hal yang membedakan SEM dengan regresi biasa maupun teknik multivariate lainnya, karena SEM membutuhkan lebih sekedar perangkat statistic yang didasarkan atas regresi biasa dan analisis varian. SEM terdiri dari 2 bagian yaitu: model variable laten dan model pengukuran. Kedua model SEM ini mempunyai karakteristik yang berbeda dengan regresi biasa. Regresi biasa pada umumnya menspedifikasikan hubungan kausa antara variabel-variabel teramati (observed variables), sedangakan pada

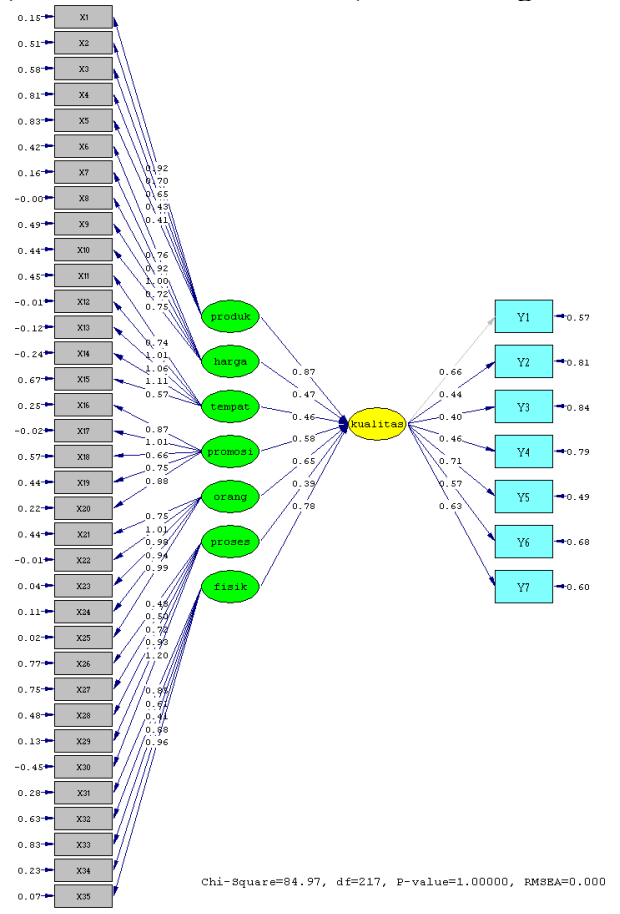

Gambar 1. Model Dasar Estimate Untuk melihat valid dan reliable, maka klik $\mathrm{T}$ - values pada kotak dengan keterangan Estimate, hasilnya. model variabel laten SEM, hubungan terjadi diantara variebel-variabel tidak teramati (unobserved variables) atau variabelvariabel laten, Hari Wijanto, Setyo,2008.

Bentuk umum dari SEM, yang dikenal juga full atau hybrid model mengandung variabel-variabel laten maupun variabelvariabel teramati yang terkait. Meskipun demikian pada beberapa penelitian, terutama dibidang ekonomi, ita banyak menemui model yang semua variabelnya adalah variabel teramati dan tidak mengandung variabel laten. Model semacam ini sering disebut sebagai path model atau model lintasan, Hari Wijanto, Setyo,2008. Menurut Bollen dan Longdari dalam bukuk Hari Wijanto, Setyo,2008 hal 34. Prosedur SEM secara umum akan mengandung tahap-tahap sebagai berikut:

1. Spesifikasi Model

2. Identifikasi Model

3. Estimasi Model

4. Pembentukan Model

5. Respesifikasi Model

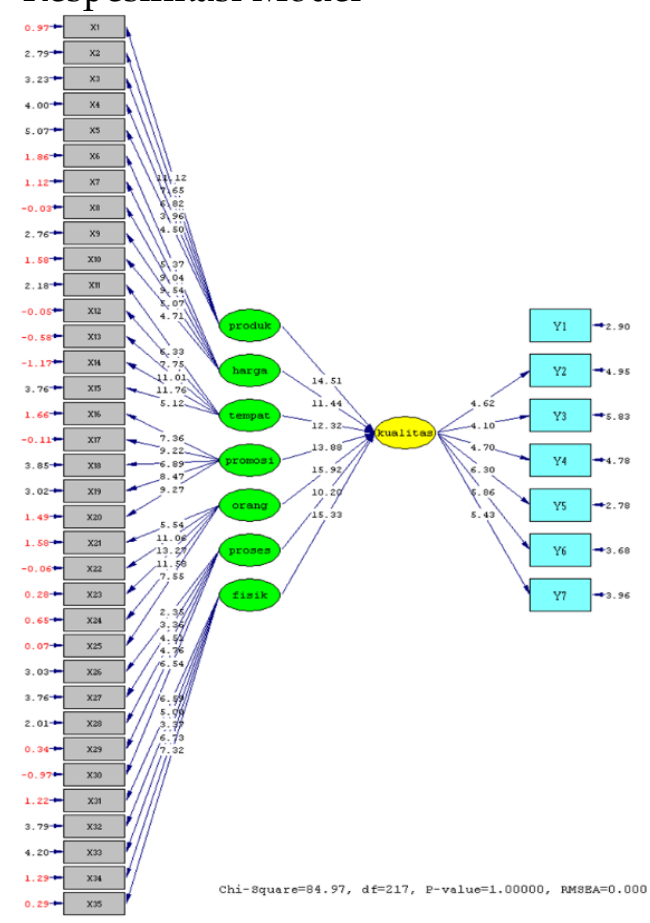

Gambar 2 Model Estimate $\mathrm{t}$ values 
Tabel 1. Goodness of Fit Model Structural Equational Model (SEM)

\begin{tabular}{|c|c|c|}
\hline No. & $\begin{array}{c}\text { UKURAN GOODNESS OF } \\
\text { FIT (GOF) }\end{array}$ & TINGKAT KECOCOKAN YANG DAPAT DITERIMA \\
\hline & \multicolumn{2}{|c|}{ ABSOLUTE FIT MEASURE } \\
\hline 1 & Statistic Chi-Square $\left(\mathrm{x}^{2}\right)$ & $\begin{array}{l}\text { Mengikuti uji statistic yang berkaitan dengan persyaratan } \\
\text { signifikan. Semakin kecil semakin baik. Dalam penelitian } \\
\text { ini dari hasil perhitungan menggunakan LISREL didapat } \\
\text { Normal Theory Weighted Least Squares Chi-Square }=84.97 \text { (P } \\
=1.00 \text { ). Tingkat kecocokan Kurang baik }\end{array}$ \\
\hline 2 & $\begin{array}{c}\text { Non - Centrality Parameter } \\
(\mathrm{NCP})\end{array}$ & $\begin{array}{l}\text { Dinyatakan dalam bentuk spesifikasi ulang dari Chi - } \\
\text { Square }\left(\mathrm{X}^{2}\right) \text {. Penilaian didasarkan atas perbandingan } \\
\text { dengan model lain. Semakin kecil semakin baik. Dari } \\
\text { penelitian ini hasil perhitungan menggunakan LISREL } \\
\text { didapat Estimated Non-centrality Parameter } \\
(\mathrm{NCP})=0.0 .90 \text { Percent Confidence Interval for NCP }=(0.0 \\
; 0.0) \text {. Tingkat kecocokan good fit (baik). }\end{array}$ \\
\hline 3 & Scaled NCP (SNCP) & $\begin{array}{l}\text { NCP yang dinyatakan dalam bentuk rata- rata perbedaan } \\
\text { setiap observasi dalam rangka perbandingan antar model. } \\
\text { Semakin kecil semakin baik. }\end{array}$ \\
\hline 4 & Goodness of Fit Index (GFI) & $\begin{array}{l}\text { Nilai berkisar antara } 0-1 \text {, dengan nilai dengan nilai lebih } \\
\text { tinggi adalah baik, GFI } \geq 0,90 \text { adalah good-fit, sedangkan } \\
0,80 \leq \mathrm{GFI} \leq 0,90 \text { adalah marginal fit. Data dari penelitian ini } \\
\text { hasil perhitungan menggunakan LISREL Goodness of Fit } \\
\text { Index }(\mathrm{GFI})=0.96 \geq 0.90 \text { artinya good }- \text { fit. }\end{array}$ \\
\hline 5 & $\begin{array}{l}\text { Root Mean Square Residuan } \\
\text { (RMR) }\end{array}$ & $\begin{array}{l}\text { Residual rata-rata antara matrik (korelasi atau kovarian) } \\
\text { teramati dan hasil estimasi. Standardized RMR } \leq 0,05 \\
\text { adalah good- fit. Data dari penelitian ini hasil perhitungan } \\
\text { menggunakan LISREL Root Mean Square Residual (RMR) } \\
=0.069 \text {. Artinya kurang baik }\end{array}$ \\
\hline 6 & $\begin{array}{l}\text { Root Mean Square Error of } \\
\text { Approximation (RMSEA) }\end{array}$ & $\begin{array}{l}\text { Rata - rata perbedaan per deegre of freedom yang } \\
\text { diharapkan terjadi dalam populasi dan bukan dalam } \\
\text { sampel. RMSEA } \leq 0,80 \text { adalah good fit, sedangkan RMSEA } \\
<0,05 \text { adalah close fit. Data dari penelitian ini hasil } \\
\text { perhitungan menggunakan LISREL } \\
\text { Square Error of Approximation (RMSEA) }=0.0, \quad \text { Root Mean } \\
\text { Percent Confidence Interval for RMSEA }=(0.0 ; 0.0) \text {, P- } \\
\text { Value for Test of Close Fit (RMSEA < 0.05) }=1.00 \text { artinya } \\
\text { Close fit. }\end{array}$ \\
\hline 7 & $\begin{array}{c}\text { Expected Cross Validation } \\
\text { Index (ECVI) }\end{array}$ & $\begin{array}{l}\text { Digunakan untuk perbandingan antar model. Semakin } \\
\text { kecil semakin baik. Pada model tunggal, nilai ECVI dari } \\
\text { model yang mendekati nilai saturated ECVI menunjukan } \\
\text { good fit. Data dari penelitian ini hasil perhitungan } \\
\text { menggunakan LISREL } \\
\text { Index }(\text { ECVI) }=32.43 \text {. 90Percent Confidence Interval for } \\
\text { ECVI }=(32.43 ; 32.43) \text {. } \\
\text { Model }=36.86 \\
=84.13 \text { ECVI for Saturated } \\
\begin{array}{l}\text { Dilihat dari data diatas ECVI } 32,43 \text { mendekati ECVI } \\
\text { saturated artinya model good fit. }\end{array}\end{array}$ \\
\hline & \multicolumn{2}{|r|}{ INCREMENTAL FIT MEASURES } \\
\hline 8 & $\begin{array}{c}\text { Tucker Lewis Index atau Non- } \\
\text { Normed Fit Index (TLI atau } \\
\text { NNFI) }\end{array}$ & $\begin{array}{l}\text { Nilai berkisar antar } 0-1 \text {, dengan nilai lenih tinggi adalah } \\
\text { lebih baik. TLI } \geq 0,90 \text { adalah good fit. Sedang } 0,08 \leq \text { TLI } \leq \\
0,90 \text { adalah marginal fit. Data dari penelitian ini hasil } \\
\text { perhitungan menggunakan LISREL Non-Normed Fit } \\
\text { Index }(\mathrm{NNFI})=1.27 \geq 0,90 \text { adalah good fit. }\end{array}$ \\
\hline
\end{tabular}




\begin{tabular}{|c|c|c|}
\hline 9 & Normed Fit Index (NFI) & $\begin{array}{l}\text { Nilai berkisar antar } 0-1 \text {, dengan nilai lenih tinggi adalah } \\
\text { lebih baik. NFI } \geq 0,90 \text { adalah good fit. Sedang } 0,08 \leq N F I \leq \\
0,90 \text { adalah marginal fit. Data dari penelitian ini hasil } \\
\text { perhitungan menggunakan LISREL Normed Fit Index } \\
(\mathrm{NFI})=1.00 \geq 0,90 \text { adalah good fit. }\end{array}$ \\
\hline 10 & $\begin{array}{l}\text { Adjusted Goodness of Fit } \\
\text { Index (AGFI). }\end{array}$ & $\begin{array}{l}\text { Nilai berkisar antar } 0-1 \text {, dengan nilai lenih tinggi adalah } \\
\text { lebih baik. AGFI } \geq 0,90 \text { adalah good fit. Sedang } 0,08 \leq \text { AGFI } \\
\leq 0,90 \text { adalah marginal fit. Data dari penelitian ini hasil } \\
\text { perhitungan menggunakan LISREL Adjusted Goodness of } \\
\text { Fit Index }(\text { AGFI }=0.82 .0,80 \leq 0,82 \leq 0,90 \text { adalah marginal } \\
\text { fit. }\end{array}$ \\
\hline 11 & Retive Fit Index (RFI) & $\begin{array}{l}\text { Nilai berkisar antar } 0-1 \text {, dengan nilai lenih tinggi adalah } \\
\text { lebih baik. RFI } \geq 0,90 \text { adalah good fit. Sedang } 0,08 \leq \text { RFI } \leq \\
0,90 \text { adalah marginal fit. Data dari penelitian ini hasil } \\
\text { perhitungan menggunakan LISREL Relative Fit Index } \\
(\mathrm{RFI})=1.00 . \geq 0,90 \text { adalah marginal fit. }\end{array}$ \\
\hline 12 & Incremental Fit Index (IFI) & $\begin{array}{l}\text { Nilai berkisar antar } 0-1 \text {, dengan nilai lenih tinggi adalah } \\
\text { lebih baik. IFI } \geq 0,90 \text { adalah good fit. Sedang } 0,08 \leq \text { IFI } \leq \\
0,90 \text { adalah marginal fit. Data dari penelitian ini hasil } \\
\text { perhitungan menggunakan LISREL Incremental Fit Index } \\
(\mathrm{IFI})=1.06 . \geq 0,90 \text { adalah good fit. }\end{array}$ \\
\hline 13 & Comparative Fit Index (CFI) & $\begin{array}{l}\text { Nilai berkisar antar } 0-1 \text {, dengan nilai lenih tinggi adalah } \\
\text { lebih baik. CFI } \geq 0,90 \text { adalah good fit. Sedang } 0,08 \leq \text { CFI } \leq \\
0,90 \text { adalah marginal fit. Data dari penelitian ini hasil } \\
\text { perhitungan menggunakan LISREL Comparative Fit Index } \\
(\mathrm{CFI})=1.00 \geq 0,90 \text { adalah good fit. }\end{array}$ \\
\hline & \multicolumn{2}{|r|}{ PARSIMONIOUS FIT MEASURES } \\
\hline 14 & $\begin{array}{l}\text { Parsimonious Goodness of Fit } \\
\text { (PGFI) }\end{array}$ & $\begin{array}{l}\text { Spesifikasi ulang dari GFI, dimana nilai lebih tinggi } \\
\text { menunjukan parsimony yang lebih besar. Ukuran ini } \\
\text { digunakan untuk perbandingan dianrata model -model. } \\
\text { Data dari penelitian ini hasil perhitungan menggunakan } \\
\text { LISREL Parsimony Goodness of Fit Index (PGFI) }=0.23 \text {. } \\
\text { PGFI tersebut adalah good fit. }\end{array}$ \\
\hline 15 & Normed Chi-Square & $\begin{array}{l}\text { Rasio antara Chi-Square dibagi deegre of freedom. Nilai yang } \\
\text { disarankan: batas bawah: } 1,0 \text { batas atas } 2,0 \text { atau 3,0 dan } \\
\text { yang lebih longgar } 5,0 \text {. Chi-Square }=84.97: \text { deegre of freedom } \\
\text { (df) } 217=0,39 \text { artinya masih didalam batas nilai Chi-Square } \\
\text { yang normal. Good fit. }\end{array}$ \\
\hline 16 & $\begin{array}{l}\text { Parsimonious Normed Fit } \\
\text { Index (PNFI) }\end{array}$ & $\begin{array}{l}\text { Nilai tinggi menunjukan kecocokan lebih baik, hanya } \\
\text { digunakan untuk perbandingan antar model alternative. } \\
\text { Data dari penelitian ini hasil perhitungan menggunakan } \\
\text { LISREL Parsimony Normed Fit Index (PNFI) }=0.25 \text {. }\end{array}$ \\
\hline 17 & $\begin{array}{l}\text { Akaike Information Criterion } \\
\text { (AIC) }\end{array}$ & $\begin{array}{l}\text { Nilai positif lebih kecil menunjukan parsimony lebih baik. } \\
\text { Digunakan untuk perbandingan antar model. Pada model } \\
\text { tunggal nilai AIC dari model yang mendekati nilai } \\
\text { saturated AIC menunjukan good fit. Data dari penelitian } \\
\text { ini hasil perhitungan menggunakan LISREL Model AIC }= \\
\text { 1456.97, Saturated AIC }=1806.00 \text {, nilai dapat dikatakan } \\
\text { mendekati artinya model adalah good fit. }\end{array}$ \\
\hline 18 & $\begin{array}{c}\text { Consistent Akaike Information } \\
\text { Criterion (CAIC) }\end{array}$ & $\begin{array}{l}\text { Nilai positif lebih kecil menunjukan parsimony lebih baik. } \\
\text { Digunakan untuk perbandingan antar model. Pada model } \\
\text { tunggal nilai CAIC dari model yang mendekati nilai } \\
\text { saturated CAIC menunjukan good fit. Data dari penelitian } \\
\text { ini hasil perhitungan menggunakan LISREL Model CAIC }\end{array}$ \\
\hline
\end{tabular}




\begin{tabular}{|c|c|l|}
\hline & & $\begin{array}{l}\text { = 3454.62. Saturated CAIC }=4435.56, \text { nilai dapat dikatakan } \\
\text { mendekati artinya model adalah good fit. }\end{array}$ \\
\hline & \multicolumn{1}{|c|}{ OTHER GOFI } \\
\hline 19 & Critical “N" $(\mathrm{CN})$ & $\begin{array}{l}\mathrm{CN} \geq 200 \text { menunjukan ukuran sampel mencukupi untuk } \\
\text { digunakan mengestimasi model. Kecocokan yang } \\
\text { memuaskan atau baik. }\end{array}$ \\
\hline
\end{tabular}

Dari tabel 1 dapat dilihat bahwa ada 5 ukuran GOF yang menunjukan kecocokan yang kurang baik dan ada 11 dari 19 jenis pengukuran, sehingga kita dapat menyimpulkan bahwa kecocokan keseluruhan model adalah Good Fit (Baik).

\section{Analisa Koefisien Korelasi}

Koefisien korelasi adalah pengukuran statistic atau asosiasi antara dua variabel. Besarnya koefisien korelasi antara $=1 \mathrm{~s} / \mathrm{d}$ 1. Koefisien korelasi menunjukan kekuatan (strength) hubungan linier dan arah hubungan dua variabel acak. Jika koefisien korelasi positif, maka kedua variabel mempunyai hubungan searah. Artinya jiak nilai variabel $X$ tinggi, maka nilai variabel $Y$ akan tinggi pula. Sebaliknya, jika koefisien korelasi negative maka kedua variabel mempunyai hubungan terbalik. Artinya jika nilai variabel $X$ tinggi, maka nilai variabel $Y$ akan menjadi rendah (dan sebalikanya).

Interprestasi dari besarnya nilai korelasi antar variabel diklasifikasikan seperti tabel dibawah ini:

Tabel 2. Interpretasi Koefisien Korelasi

\begin{tabular}{|c|c|}
\hline Interval Koefisien & Tingkat Hubungan \\
\hline $0,00-0,199$ & Sangat Rendah \\
\hline $0,20-0,399$ & Rendah \\
\hline $0,40-0,599$ & Sedang \\
\hline $0,60-0,799$ & Kuat \\
\hline $0,80-1,00$ & Sangat Kuat \\
\hline
\end{tabular}

Setelah melihat melihat dari tabel diatas selanjutnya dapat kita memberikan kesimpulan mana variabel yang memiliki pengaruh kuat terhadap persepsi kualitas dengan merangkumnya dari gambar yang telah diolah oleh program LISREL seperti tabel dibawah ini:

Tabel 3 Pengaruh Besarnya Variabel Laten Eksogen Terhadap Variabel Laten Endogen

\begin{tabular}{|c|c|c|c|c|}
\hline $\begin{array}{c}\text { Variabel Laten } \\
\text { Eksogen }\end{array}$ & $\begin{array}{c}\text { Variabel } \\
\text { Laten } \\
\text { Endogen }\end{array}$ & $\begin{array}{c}\text { Koefisien } \\
\text { Konstruk }\end{array}$ & Uji t & Kesimpulan \\
\hline PRODUK (Y1) & KUALITAS & 0.87 & 14.51 & Signifikan \\
\hline HARGA (Y2) & KUALITAS & 0.47 & 11.44 & Signifikan \\
\hline TEMPAT (Y3) & KUALITAS & 0.46 & 12.32 & Signifikan \\
\hline PROMOSI (Y4) & KUALITAS & 0.58 & 13.88 & Signifikan \\
\hline ORANG (Y5) & KUALITAS & 0.65 & 15.92 & Signifikan \\
\hline PROSES (Y6) & KUALITAS & 0.38 & 10.20 & Signifikan \\
\hline FISIK (Y7) & KUALITAS & 0.78 & 15.33 & Signifikan \\
\hline
\end{tabular}

Sumber: Hasil Pengolahan data menggunakan LISREL

Melihat dari tabel diatas dapat dilihat

Uji t hasil observasi lebih besar dari $t$ tabel artinya semua variabel dinyatakan signifikan selanjutnya dapat diurutkan variabel mana yang memiliki harapan dari responden yang paling tinggi berpengaruh terhadap kualitas untuk lebih jelasnya mari kita lihat tabel dibawah ini:
Tabel 4.. Urutan Serta Tingkat Hubungan Bauran Pemasaran Terhadap Persepsi Kualitas

\begin{tabular}{|c|c|c|c|}
\hline No. & $\begin{array}{c}\text { Variabel } \\
\text { Laten } \\
\text { Eksogen }\end{array}$ & $\begin{array}{c}\text { Koefisien } \\
\text { Konstruk }\end{array}$ & $\begin{array}{c}\text { Tingkat } \\
\text { Hubungan }\end{array}$ \\
\hline 1 & PRODUK & 0.87 & Sangat Kuat \\
\hline 2 & FISIK & 0.78 & Kuat \\
\hline 3 & ORANG & 0.65 & Kuat \\
\hline 4 & PROMOSI & 0.58 & Sedang \\
\hline 5 & HARGA & 0.47 & Sedang \\
\hline 6 & TEMPAT & 0.46 & Sedang \\
\hline 7 & PROSES & 0.36 & Rendah \\
\hline
\end{tabular}


Menurut tabel diatas maka dapat kita lihat ternyata harapan dari mahasiswa akan produk atau kualitas pendidikan yang baik menjadi faktor paling berpengaruh karena memiliki tingkat hubungan "sangat kuat" terhadap persepsi kualitas dengan dibuktikan memiliki angka koefisien konstruk sebesar 0,87. Di STBA JIA kualitas pendidikan distandarisasi dengan dibuktikan para lulusannya salah satu sebagai syarat pengambilan ijazah kelulusan diwajibkan memiliki test kemampuan bahasa dengan standart Internasional contoh untuk mahasiswa bahasa Inggris S1 harus memiliki test TOEFL Institusional minimum score 600 dan untuk mahasiswa bahasa Jepang diwajibkan lulus test Noryoukusiken level 3 (N3) yang diselenggarakan hanya oleh The Japan Foundation. Melihat dari harapan diatas maka STBA JIA seharusnya harus dapat terus mempertahankan outputnya atau lulusannya sehingga kualitas para lulusan tetap terjaga kualitasnya.

Selanjutnya menempati urutan kedua yang cukup signifikan yaitu fisik (bentuk fisik) dengan koefisien konstruk 0,78 dengan tingkat hubungan yang "kuat" terhadap persepsi kualitas, artinya mahasiswa menaruh harapan cukup yang besar terhadap bentuk fisik terutama sarana prasarana yang tersedia seperti perpustakaan, laboratorium, dan lain sebagainya tolok ukur persepsi kualitas. Untuk saat ini di STBA JIA memang belum sepenuhnya memiliki sarana prasarana yang cukup memadai contohnya perpustakaan koleksi buku - buku belum begitu lengkap, lapangan parkir yang terbatas dan masih banyak kekurangan sarana prasarana.

Selanjutnya urutan ketiga dengan koefisien konstruk 0,65 masih kedalam kategori memiliki hubungan yang kuat terhadap persepsi kulitas yaitu orang (people) yang dapat diartikan SDM yang ada seperti staff penunjang kegiatan belajar mengajar mulai dari staff akademik, administrasi, umum, sampai keamanan, dimana para mahasiswa menaruh harapan untuk senantiasa dapat melayani dengan baik.

Selanjutnya urutan keempat dengan koefisien konstruk 0,58 yaitu promosi memiliki hubungan yang "sedang" tehadap persepsi kualitas, harapan mahasiswa promosi dapat ditingkatkan guna peningkatan citra almamaternya, sejauh mana almamaternya dapat dikenal oleh masyarakat alumni akan merasa bangga dan tentunya bagi STBA JIA sendiri akan selalu berupaya mempertahankan kualitas yang sudah dimilikinya serta meningkatkan upaya yang sudah ditempuhnya.

Untuk harga dan tempat memiliki koefisien konstruk yang hampir sama yaitu 0,47 dan 0,46 artinya memiliki hubungan yang "sedang" terhadap persepsi kualitas dikarenakan untuk harga (Price) tentunya setiap orang menginginkan harga rendah sementara untuk menunjang kualitas yang diharapkan tentunya memiliki beban biaya yang tinggi. Dari segi tempat (Place) memiliki hubungan yang "sedang" dikarenakan tempat yang strategis tentunya harapan semua orang terutama mudah dicapai oleh akses kendaraan, Perguruan Tinggi yang berkualitas tentunya mencari tempat yang strategis tidak berada di jauh pusat kota atau berada dipedalaman, demikian juga persepsi kualitas dari mahasiswa, artinya apabila hendak membangun pengambangan untuk gedung kampus selanjutnya pilihlah tempat yang strategis.

Terakhir ternyata "proses" dari ketujuh bauran pemasaran dengan koefisien konstruk 0,36 yang berarti memiliki hubungan yang "rendah" terhadap persepsi kualitas. Sehingga kemungkinan tidak signifikan pengaruhnya terhadap persepsi kualitas.

\section{KESIMPULAN DAN SARAN Kesimpulan}

Setelah semua tahap penelitian dilakukan, mulai dari pembuatan proposal penelitian, kemudian pengkajian teori, penyusunan instrument penelitian yang disertai dengan uji coba dan penyempurnaan instrument penelitian, 
sampai dengan pengumpulan data, pengolahan dan analisis data.

Pada akhirnya peneliti dapat menyimpulkan hasil penelitian tentang Pengaruh Bauran Pemasaran Jasa Terhadap Persepsi Kualitas STBA JIA Bekasi yakni; Pertama, Bauran pemasaran Produk "Product" memiliki pengaruh positif serta tingkat hubungan yang sangat kuat terhadap persepsi kualitas dibuktikan dengan nilai koefisien konstruk 0,87. Kedua, Bentuk Fisik "Physical Evident" memiliki pengaruh positif serta tingkat hubungan yang kuat terhadap persepsi kualitas dibuktikan dengan nilai koefisien konstruk 0,78 . Ketiga, Orang "People" memiliki pengaruh positif serta tingkat hubungan yang cukup kuat terhadap persepsi kualitas dibuktikan dengan nilai koefisien konstruk 0,65. Keempat, Promosi "Promotion" memiliki pengaruh positif serta tingkat hubungan yang cukup kuat terhadap persepsi kualitas dibuktikan dengan nilai koefisien konstruk 0,58. Kelima, Harga "Price" memiliki pengaruh positif serta tingkat hubungan yang cukup kuat terhadap persepsi kualitas dibuktikan dengan nilai koefisien konstruk 0,47. Keenam, Tempat "Place" memiliki pengaruh positif serta tingkat hubungan yang cukup kuat terhadap persepsi kualitas dibuktikan dengan nilai koefisien konstruk 0,46 dan Ketujuh, Proses "Process" memiliki pengaruh positif serta tingkat hubungan yang lemah terhadap persepsi kualitas dibuktikan dengan nilai koefisien konstruk 0,36 .

\section{Saran}

Penelitian ini telah menunjukkan bahwa bauran pemasaran jasa sangat berpengaruh terhadap persepsi kualitas yang ada di sebuah lembaga pendidikan, artinya apabila salah dalam pengambilan keputusan terutama dalam memprioritaskan mana yang harus didahulukan dalam meningkatkan bauran pemasaran jasa, dengan mengadakan penelitian ini maka kita dapat melihat mana yang paling kuat pengaruhnya terhadap persepsi mahasiswa terhadap kualitas yang telah diberikan selama ini. Sehingga memudahkan pihak Yayasan serta pengelola lembaga pendidikan untuk mengembangkan bauran pemasaran jasa.

Hasil penelitian ini memberikan beberapa implikasi, antara lain: (1) implikasi terhadap perencanaan dan pengembangan kurikulum pendidikan yang berbasis kompetensi untuk Sekolah Tinggi Bahasa Asing JIA, (2) implikasi terhadap pengembangan dan penyusunan silabus dan SAP pendidikan, (3) implikasi terhadap cara pandang dosen terhadap siswa, (4) implikasi terhadap pendidikan tenaga kependidikan dan (5) implikasi terhadap usaha sadar sebagai peran penting intitusi pendidikan dalam turut merumuskan, mengembangkan serta mewujudkan sarana prasarana yang baik, aman dan nyaman.

1. Pengembangan kurikulum pendidikan yang lebih aplikatif, serta hendaknya merancang dengan cermat dan disesuaikan dengan kebutuhan para stakeholder.

2. Seletah melalui proses pengembangan kurikulum maka dirancang kembali Silabus dan SAP untuk segera diterapkan.

3. Membuat ekstra kulikuler yang lebih bermanfaat tergadap mahasiswa

4. Mengadakan kerjasama dengan berbagai instansi untuk memudahkan para lulusan dapat langsung diterima kerja.

5. Tetap memberikan standart kompetensi yang tinggi terhadap para lulusan

6. Membangun kembali atau merenovasi kembali sarana prasarana yang telah ada

\section{DAFTAR PUSTAKA}

Kotler, Philip, 1987, Marketing, Jilid 1,Jakarta, Penerbit : Erlangga.

Kotler, Philip, 1988, Marketing, Jilid 2, Jakarta, Penerbit : Erlangga.

T. Widjaja, Bernard, 2009, Life Style Marketing, Gramedia Pustaka Utama

Lupiyoadi, Rambat, 2001,Manajemen Pemasaran Jasa : Teori dan Praktek, Edisi Pertama, Jakarta, Salemba Empat. 
Alma, Buchari dan Hurriyati, Ratih , 2008. Manajemen Corporate dan Strategi Pemasaran Jasa Pendidikan. Bandung. Penerbit PT. Alfabeta.

Kotler, Philip dan Amstrong, Gary, 2004. Principles of Marketing 7e . DasarDasar Pemasaran. Diterjemahkan oleh Alexander Sindoro, Jilid 1 Edisi Kesembilan, Jakarta. PT. Ikrar Mandiriabadi

Sarjono, Haryadi dan Julianita, Winda, 2011. SPSS Vs LISREL :Sebuah Pengantar, Aplikasi Riset, Jakarta, Penerbit Salemba Empat.

Sunarsi, D. (2020). Pengaruh Bauran Pemasaran Dan Kualitas Pelayanan
Terhadap Kepuasan Konsumen Pada Giant Dept Store Cabang BSD Tangerang. E-Mabis: Jurnal Ekonomi Manajemen dan Bisnis, 21(1), 7-13.

Hari Wijanto, Setyo, 2008. Structural Equation Modeling dengan LISREL 8.80, Jogyakarta, Penerbit Graha Ilmu. JR Sitinjak, Tumpal dan Sugiarto, 2006. LISREL. Jogyakarta, Penerbit Graha Ilmu.

Kuncoro Mudrajad, 2003. Metode Riset Untuk Bisnis E Ekonomi, Jakarta, Penerbit Erlangga

Usman Husaini, 2008. Pengantar Statistika. Jakarta, Penerbit Bumi Aksara 